\title{
STUDI KURIKULUM PEMBELAJARAN PENDIDIKAN GENDER PADA LEMBAGA PENDIDIKAN ISLAM (STUDI KASUS DI SD ALAM ARROHMAH PUTRI HIDAYATULLAH MALANG)
}

\author{
Suhar Nanik ${ }^{1}$
}

\begin{abstract}
The gender understanding is determined by the understanding for everyeach of men and woman that based on space and time. The period in which a people in an order based education elementary school of Islam into a future that can impact one's mindset so that later in life will become an adult who has the perspective of gender with various categories of space and time. The education elementary school will guide for people become an distinguish men and woman right into place. Comprehensive accuracy in distinguishing men in woman are create a harmony in life. Harmony in life became an ideal life that should be built by joined between men and woman as the same. It all make them fulfill their needed and survival. This research was carried out by using a riew of the curriculum in education elementary school of Islam and study was done to prove that finally there is no curriculum that introduced for gender. There is no mention to illustrate and to explain of the differences between men and woman by socio and cultural. This understanding is very important in education elementary school of Islam for child mentally physical changes. The result of this research indicated by the fact and document that there is no significant curriculum clearly implied that talking about gender.
\end{abstract}

Keywords: Gender, Curriculum, Elementary School.

\section{A. Pendahuluan}

Gender menjadi sebuah pembicaraan yang cukup hangat bahkan menjadi isu yang sangat menarik. Dianggap menarik, karena gender dapat dilihat dari perbagai macam persoalan. Misalnya gender dalam perspektif, kesenjangan gender, persoalan gender, kekerasan gender dan lain-lain. Topik gender merupakan topik yang dibahas dalam peradaban modern. Hal ini dikarenakan peradaban modern lebih menekankan pada pemikiran-pemikiran yang posivitisme. Basis pemahaman membedakan laki-laki dan perempuan pada penekanan analisa rasional. Ketika akal

1 Dosen Fakultas Ilmu Tarbiyah dan Keguruan UIN Maulana Malik Ibrahim Malang Jl. Gajayana No. 50 Malang 65144 
pikiran tidak bisa menerima sebuah pengkategorian tentang laki-laki dan perempuan, maka keduanya tidak bisa dibedakan artinya sama.

Gender merupakan topik pembicaraan yang ada dalam setiap elemen fungsi dalam sendi-sendi kehidupan. Swedia sebagai negara yang patut di contoh dalam hal persamaan gender. PBB menempatkan posisi negara ini sebagai negara percontohan dan persamaan gender. Ini disebabkan negara ini memberikan cuti bagi perempuan yang melahirkan hingga 69 minggu. Negara ini bahkan dikatakan fleksibel dan sangat toleran terhadap ibu hamil. Norwegia sebagai negara satu-satunya yang meloloskan gender equity dalam aturan perundangundangannya. Negara ini menempatkan posisi perempuan di parlemen sebanyak $40 \%$ dan pendapatan perempuan merupakan pendapatan terbesar diantara negara-negara lainnya. Selain itu, dalam penggunaan dan pilihan kata ganti jenis kelamin, juga dibahas dalam penggunaan bahasa untuk membedakan sebutan laki-laki maupun perempuan. Pada hampir semua bahasa, pilihan kata ganti jenis kelamin masih terbedakan namun tidak dengan bahasa Jerman. Ini menandakan bahasa Jerman menyediakan kata ganti yang tidak perlu mempersoalkan apakah jenis kelaminnya laki-laki atau perempuan. Oleh karena itu, gender menjadi bahan pembicaraan pada hampir semua negara yang menggunakan bahasa sebagai alat komunikasi dalam melakukan interaksi sosial. Sebagaimana Eicher, et al. (2013) mengatakan bahwa dalam tatanan bahasa kerap sekali gender menjadi pertimbangan dalam menentukan jenis kelamin. Aturan bahasa ini yang yang dianut oleh beberapa bahasa internasional diantaranya adalah bahasa Perancis, Spanyol, Italia dan bahkan Jerman menganut tiga perbedaan untuk menentukan jenis kelamin yaitu laki-laki, perempuan dan netral (kata pengganti yang netral (Eicher, et, al, 2013).

Di Turki, kurikulum dipergunakan bagi sekolah dasar yang meliputi bidang matematika, ilmu alam atau sains, ilmu sosial, ilmu kehidupan dan bahasa dan kebudayaan. Namun, dalam memperbarui kurikulum agar lebih berkembang dengan keadaan zaman, mereka melakukan reformasi terhadap kurikulum-kurukulum. Diantaranya, seperti kurikulum sosial, individu, ekonomi, sejarah dan budaya untuk dipadukan dengan kurikulum Uni Eropa. Dengan memadukan kurikulum yang lebih reformis, dianggap sebagai senjata ampuh dalam mempengaruhi kebijakan pemerintahnya (Yusuf Koc, dkk. 2007). Kondisi berbeda ditemui pada lembaga pendidikan Indonesia. 
Misalnya, di Sekolah Dasar Alam Arrohmah, kurikulum yang digunakan adalah kurikulum yang sudah ditentukan oleh dinas pendidikan dan kebudayaan. Meskipun demikian, kurikulum mandiri tetap menjadi idiologi khusus yang menjadi ciri dari Sekolah dasar tersebut. Sebagai contoh, kurikulum hafalan Al Qur'an dan Hadist yang telah ditentukan berdasarkan tingkatan kelas.

\section{B. Pengertian Gender}

Gender merupakan sebuah perlakuan membedakan laki-laki dan perempuan dalam pandangan norma dan budaya yang ada di sebuah masyarakat. Tidak ada yang salah dengan gender. Istilah gender hanyalah sebuah istilah yang sangat ditentukan oleh kapan dan dimana laki-laki serta perempuan tersebut tinggal dan dibedakan. Keadaan dan situasi tersebut menentukan pandangan masyarakat atas status laki-laki dan perempuan. Keberadaan tempat dan waktu status individu merupakan penentu utama dalam melihat peran laki-laki dan perempuan yang dianggap pantas dan layak dalam pandangan masyarakat.

Dalam teori sosial makro tentang gender, penempatan perbedaan jenis kelamin berskala luas. Adapun teori yang mendukung adalah teori fungsionalisme, teori konflik analitis dan teori sistem dunia neo-marxism. Dari ketiga teori tersebut, akhirnya memperoleh satu kesepakatan bahwa tempat utama bagi perempuan adalah sebuah tempat yang khusus yaitu keluarga (rumah tangga). Meskipun perempuan menjadi pelaku dalam kegiatan ekonomi pasar, namun pada akhirnya akan beralih fungsi sebagai upaya untuk memahami fungsi keluarga. Selain itu, ketiga teori tersebut juga berkonsentrasi untuk menerangkan stratifikasi gender yang pada umumnya masih terdapat kerugian pada posisi perempuan (George Ritzer dan Douglas J. Goodman, 2005 : 408411). Perempuan di Indonesia menempati posisi-posisi strategis sebagai guru, manajer perusahaan, dokter dan lain sebagainya. Selain tugas dan kewajiban perempuan untuk berperan secara maksimal di ruang publik, perempuan juga memerankan diri sebagai ibu yang mengurus anak dan rumah tangganya.

Dalam teori sosial mikro, terjadi perdebatan tajam terkait interaksi sosial dan perbedaan gender. Pembahasan dalam teori ini didukung oleh teori interaksionisme simbolik dan etnometodologi. Baik interaksionisme simbolik maupun etnometodologi, sama-sama menghargai dan menerima 
jenis kelamin sebagai konsep normatif dalam lingkungan institusional. Pesan yang disampaikan melalui media iklan, televisi, film, buku, majalah, secara langsung menceritakan kepada anak-anak dan orang dewasa tanpa intervensi interaksi dan membedakan jenis kelamin. Interaksi yang dibangun tidak perlu harus membedakan apakah dengan laki-laki ataukah dengan perempuan (George Ritzer dan Douglas J. Goodman, 2005 : 412-414). Teori ini mengesampingkan adanya pembedaan antara laki-laki dan perempuan seperti halnya beberapa tayangan televisi yang dibintangi komedian Sule. Artis tersebut seringkali muncul di televisi dengan memakai kostum perempuan. Padahal, secara nyata berjenis kelamin laki-laki. Interaksi simbolik tidak membedakan dan tidak mengharuskan para pelaku harus sesuai dengan tuntutan dan nilai masyarakat terhadap jenis kelaminnya.

\section{Gender dalam Islam}

Pemahaman tentang laki-laki dan perempuan merupakan pokok dari kajian-kajian agama, budaya dan masyarakat. Tiap-tiap agama, budaya dan masyarakat melakukan identifikasi yang berbeda status laki-laki dan perempuan sehingga memunculkan fungsi dan peran yang berbeda. Dalam sebuah lingkungan keluarga yang memegang erat aturan agama, seringkali membuat orang tua melakukan kesalahan dalam mengidentifikasi peran anaknya yang dianggap menyalahi aturan agama. Perempuan dalam aturan agama dan budaya, seharusnya memiliki penampilan yang lemah lembut dan memakai pakaian yang tertutup untuk menutupi lekuk tubuhnya. Namun, apabila aturan tersebut tidak dilakukan oleh anak perempuan tadi, maka dianggap sebagai anak yang mengalami kelainan identitas keperempuannanya. Hal tersebut sebagaimana ditulis oleh Sultan dan Mehmet (2006) yang menyatakan ruang lingkup keluarga yang amat sangat religius terhadap keyakinan agama tertentu, telah membuat anak menjadi seorang yang diidentifikasi mengalami kelainan identitas gender, padahal menurut tes kejiwaan menyatakan bahwa anak tersebut adalah normal.

Al Qur'an menempatkan posisi perempuan sejajar dengan laki-laki. Kajian tentang perempuan tersebut meliputi tiga hal yakni: pertama, Al Qur'an mengakui adanya masyarakat patriarkhi. Laki-laki menjadi pusat kekuasaan. yang melahirkan konsep Tuhan adalah sang Bapak, para rasul adalah Bapak, sang Bapak adalah laki-laki, sang lelaki adalah 
sang pemimpin. Namun, ini semua tidak harus dibuat kesimpulan bahwa Al Qur'an adalah kitab suci yang patriakhis. Dalam ayat-ayat tersebut, meskipun secara literal menggunakan bentuk laki-laki namun memiliki pengertian perempuan. Kedua, isu seksualitas dan gender dalam Islam. Al Qur'an hanya menempatkan perbedaan antara laki-laki dengan perempuan pada aspek biologis. Al Qur'an tidak menjadikan perbedaan laki-laki dengan perempuan dalam tatanan etika dan moral karena keduanya dianggap sama. Ketiga, wacana tentang keluarga dan perkawinan. Al Qur'an mendukung penuh kesetaraan antara laki-laki dan perempuan. Hubungan antara orang tua dan anak lebih ditekankan pada kewajiban bukan pada menuntut hak. Adapun kata dharaba dalam surat al-Nisa': 34 tidak selalu dimaknai dengan memukul, tetapi juga bisa dimaknai dengan makna-makna lainnya. Misalnya, dimaknai dengan "memberikan contoh". Bahkan Al Qur'an mengajarkan bahwa dalam perkawinan harus didasarkan pada cinta, permaafan, keharmonisan dan ketenangan (Asma Barlas, 2003).

Kecenderungan terhadap ketidak siapan dari para kaum lakilaki apabila gender diperkenalkan sebagai sebuah topik yang harus dipahami dan dimengerti. Konsep ini kemudian yang terimplementasikan secara baik dalam sistem sosial masyarakat. Laki-laki menganggap bahwa apabila topik gender semakin populer pada semua kalangan, maka akan mengancam dominasi yang telah terbentuk. Sebagaimana ditulis Mufidah, mengindikasikan adanya sensitivitas santri dan santriwati terhadap pemahaman gender. Kaum santri lebih cenderung menginginkan sosok perempuan yang melayani suami dengan baik serta tidak menginginkan istrinya lebih pintar darinya apalagi sampai menjadi aktivis. Sedangkan kaum santriwati berpandangan lain tentang laki-laki yang seharusnya tidak melakukan pengekangan terhadap perempuan dan tidak melakukan poligami atau menduakannya (Mufidah, 2010).

\section{Peran Guru dalam Pendidikan Gender Berbasis Islam}

Pendidikan Islam tidak mengajarkan perbedaan laki-laki dengan perempuan sebab dipandang semua hamba Allah adalah sama kecuali Iman dan Taqwanya. Guru merupakan sosok yang memiliki kemampuan lebih dalam mendidik dan mengajar murid-murid. Kemampuan lebih yang dimiliki guru, tidak hanya pada mata pelajaran yang menjadi tanggung jawabnya. Namun seharusnya, kemampuan tersebut ditambah 
dengan kebutuhan anak didiknya dalam menghadapi perkembangan kehidupan sehingga selayaknya disesuaikan seperti kemampuan mengenali perubahan manusia dari bayi menjadi anak-anak kemudian menjadi dewasa. Pertumbuhan dan perkembangan individu yang terjadi pada laki-laki berbeda dengan perempuan baik secara fisik maupun emosional.

Perkembangan secara fisik marupakan perubahan yang terjadi secara alamiah dan adikodrati sebagaimana yang telah diberikan oleh Allah SWT. Perubahan fisik yang terjadi pada laki-laki dan perempuan cenderung sama pada tiap-tiap wilayah dimanapun mereka berada. Lakilaki akan mengalami perubahan hormon testosteron yang mengakibatkan membesarnya kelenjar tenggorokan, tumbuhnya bulu-bulu halus di dada, ketiak dan munculnya kumis dan jenggot. Perempuan juga akan mengalami perubahan hormonal berupa hormon estrogen dan progesteron yang menyebabkan wanita tersebut tumbuh buah dada dan mengalami menstruasi. Perubahan secara fisik ini terjadi pada setiap laki-laki dan perempuan yang tidak dipengaruhi oleh kondisi sosial dan budaya. Sedangkan perubahan yang terjadi pada emosional laki-laki dan perempuan merupakan manifestasi dari keberadaan dan keadaan sosial dan budaya laki-laki dan perempuan tersebut.

Perubahan emosional merupakan cerminan dari perubahan mental dari masing-masing individu. Pada tataran selanjutnya, perubahan mental mengungkapkan hal-hal yang bersifat emosional yang merupakan bentukan dari kondisi sosial budayanya. Hal itu terlihat dari cara mereka menggunakan pakaian, berkomunikasi dan berlaku dalam sebuah tindakan. Guru yang mampu memahami kebutuhan anak sekolah dasar, seharusnya memahami bahwa pemahaman laki-laki dan perempuan menjadi tumbuh dan berkembang. Perubahan yang menyebabkan laki-laki dan perempuan menjadi berbeda dalam kondisi sosial dan budayanya merupakan topik dalam kajian gender.

Dalam memahami gender bukan berarti anak didik yang berada di sekolah dasar dituntut untuk melakukan kajian tentang gender. Hal itu memiliki kesamaan dengan kajian-kajian yang dilakukan oleh golongan akademisi yang sudah dewasa dengan segala persoalan tentang gender. Gender diperkenalkan dalam kurikulum sebagai upaya untuk mengurangi perbedaan yang selama ini masih terjadi 
dalam memandang perbedaan antara laki-laki dan perempuan. Guru bisa menjelaskan dan memberikan pemahaman kepada anak sekolah dasar bahwa mana perbedaan laki-laki dan perempuan yang bersifat adikodrati dan mana yang bersifat bentukan dari sosial budaya.

\section{Tabel 1. Ringkasan dari berbagai Teori Feminisme}

\begin{tabular}{|c|c|c|}
\hline $\begin{array}{l}\text { Variasi mendasar teori feminism - } \\
\text { menjawab pertanyaan deskriptif: } \\
\text { "apa peran perempuan?" }\end{array}$ & & $\begin{array}{l}\text { Perbedaan dalam teori - menjawab } \\
\text { pertanyaan yang menjelaskan, } \\
\text { "mengapa situasi wanita seperti } \\
\text { itu?" }\end{array}$ \\
\hline $\begin{array}{l}\text { Posisi wanita dan pengalamannya } \\
\text { di dalam kebanyakan situasi yang } \\
\text { berbeda dengan laki-laki. }\end{array}$ & $\begin{array}{l}\text { PERBEDAAN } \\
\text { GENDER }\end{array}$ & $\begin{array}{l}\text { Feminism cultural } \\
\text { Institusional } \\
\text { Eksistensi dan Fenomenologi }\end{array}$ \\
\hline $\begin{array}{l}\text { Posisi wanita dikebanyakan situasi } \\
\text { tak hanya berbeda, tetapi juga } \\
\text { kurang beruntung atau tak setara } \\
\text { dengan posisi lelaki }\end{array}$ & $\begin{array}{l}\text { KETIMPANGAN } \\
\text { GENDER }\end{array}$ & \begin{tabular}{|l|} 
Feminism Liberal \\
Marxian: \\
Penjelasan Marx dan Engels \\
Penjelasan Marxian Kontemporer \\
\end{tabular} \\
\hline $\begin{array}{l}\text { Wanita ditindas, tak hanya dibedakan } \\
\text { atau tak setara, tetapi secara aktif } \\
\text { dikekang, disubordinasi, dibentuk } \\
\text { dan digunakan, dan disalahgunakan } \\
\text { oleh lelaki. }\end{array}$ & $\begin{array}{l}\text { PENINDASAN } \\
\text { GENDER }\end{array}$ & $\begin{array}{l}\text { Feminisme Psikoanalisis } \\
\text { Feminisme Radikal } \\
\text { Feminisme Sosialis }\end{array}$ \\
\hline $\begin{array}{l}\text { Pengalaman wanita tentang } \\
\text { pembedaan, ketimpangan dan } \\
\text { berbagai penindasan menurut posisi } \\
\text { sosial mereka. }\end{array}$ & $\begin{array}{l}\text { PENINDASAN } \\
\text { STRUKTURAL }\end{array}$ & $\begin{array}{l}\text { Feminism Sosialis } \\
\text { Teori Interseksional }\end{array}$ \\
\hline $\begin{array}{l}\text { FEMINISME DAN POST- } \\
\text { MODERNISME }\end{array}$ & & \\
\hline
\end{tabular}

Sumber: George Ritzer dan Douglas J. Goodman ( 2005 : 415)

\section{E. Kurikulum pendidikan Gender}

Kurikulum yang terdapat di Sekolah Dasar Alam Arrohmah merupakan kurikulum yang menganut kurikulum yang ditetapkan oleh Dinas Pendidikan dan Kebudayaan. Adapun kurikulum yang ditetapkan adalah kurikulum agama dan akhlak mulia, kewarganegaraan dan kepribadian, ilmu pengetahuan dan teknologi, estetika, jasmani, olah raga dan kesehatan. Setiap kurikulum mempunyai cakupan materi dan topik yang mengacu pada kurikulum yang ditetapkan. Namun, 
Suhar Nanik - Studi Kurikulum Pembelajaran Pendidikan Gender...

kurikulum gender tidak dimasukkan dalam struktur kurikulumnya. Tabel 2 menjelaskan struktur kurikulum Sekolah Dasar Alam Arrohmah.

Tabel 2. Kurikulum Sekolah Dasar Alam di Lembaga Pendidikan Arrohmah.

\begin{tabular}{|c|c|c|}
\hline No & $\begin{array}{c}\text { Kelompok } \\
\text { Mata Pelajaran }\end{array}$ & Cakupan \\
\hline 1 & $\begin{array}{c}\text { Agama dan akhlak } \\
\text { mulia }\end{array}$ & $\begin{array}{l}\text { Untuk membentuk peserta didik menjadi manusia yang beriman } \\
\text { dan bertaqwa kepada Tuhan Yang Maha Esa serta berakhlak } \\
\text { mulia. Akhlak mulia mencakup etika, budi pekerti atau moral } \\
\text { sebagai perwujudan dari pendidikan agama }\end{array}$ \\
\hline 2 & $\begin{array}{l}\text { Kewarganegaraan } \\
\text { dan Kepribadian }\end{array}$ & $\begin{array}{l}\text { Untuk peningkatan kesadaran dan wawasan peserta didik akan } \\
\text { status, hak dan kewajiban dalam kehidupan bermasyarakat, } \\
\text { berbangsa dan bernegara, serta peningkatan kualitas dirinya } \\
\text { sebagai manusia. Kesadaran dan wawasan termasuk wawasan } \\
\text { kebangsaan, jiwa dan patriotisme bela negara, penghargaan } \\
\text { terhadap hak-hak asasi manusia, kemajemukan bangsa, } \\
\text { pelestarian lingkungan hidup, kesetaraan gender, demokrasi, } \\
\text { tanggung jawab sosial, ketaatan pada hukum, ketaatan } \\
\text { membayar pajak dan sikap serta prilaku anti korupsi, kolusi } \\
\text { dan nepotisme. }\end{array}$ \\
\hline 3 & $\begin{array}{l}\text { Ilmu Pengetahuan } \\
\text { dan Teknologi }\end{array}$ & $\begin{array}{l}\text { Untuk memperoleh kompetensi dasar ilmu pengetahuan dan } \\
\text { teknologi serta membudayakan berpikir ilmiah serta kritis, } \\
\text { kreatif dan mandiri. }\end{array}$ \\
\hline 4 & Estetika & $\begin{array}{l}\text { Untuk meningkatkan sensitivitas, kemampuan mengekspresikan } \\
\text { dan mengapresiasi keindahan dan harmoni. Kemampuan } \\
\text { itu mencakup apresiasi dan ekspresi baik dalam kehidupan } \\
\text { individual sehingga mampu menikmati dan mensyukuri hidup, } \\
\text { maupun dalam kehidupan sosial sehingga mampu menciptakan } \\
\text { kebersamaan yang harmonis. }\end{array}$ \\
\hline 5 & $\begin{array}{l}\text { Jasmani, Olahraga } \\
\text { dan Kesehatan }\end{array}$ & $\begin{array}{l}\text { Untuk meningkatkan potensi fisik serta membudayakan } \\
\text { sportivitas dan kesadaran hidup sehat. Budaya hidup sehat } \\
\text { termasuk kesadaran, sikap dan prilaku hidup sehat yang } \\
\text { bersifat individual ataupun yang bersifat kolektif kemasyarakatan } \\
\text { seperti menghindari perilaku seks bebas, narkoba, HIVIAIDS, } \\
\text { demam berdarah, muntaber, dan penyakit lain yang potensial } \\
\text { untuk mewabah. }\end{array}$ \\
\hline
\end{tabular}

(Data sekunder, SD Alam di Lembaga Pendidikan Arrohmah 2014) 
Kurikulum SD Alam di Lembaga Pendidikan Arrohmah memuat pula uraian yang sangat jelas untuk menggambarkan masing-masing dari kurikulum tersebut. Penjelasan ini dibuat sebagai acuan bagi pengajar dan pendidik bagaimana menjelaskan kepada para anak didiknya tentang tema dan topik sesuai dengan standar kurikulum. Adapun penjelasan dari tiap-tiap kurikulum tersebut adalah sebagai berikut:

a. Pendidikan Agama Islam

Pendidikan Agama Islam menekankan keseimbangan, keselarasan, dan keserasian antara hubungan manusia dengan Allah SWT, hubungan manusia dengan sesama manusia, hubungan manusia dengan diri sendiri, dan hubungan manusia dengan alam sekitarnya.

Materi ini juga diberikan bersamaan dengan materi diniyah, karena SD Alam di Lembaga Pendidikan Arrohmah ini berada dalam lingkungan Pesantren Hidayatullah Malang.

b. Pendidikan Kewarganegaraan

Mata pelajaran Pendidikan Kewarganegaraan bertujuan agar peserta didik :

1. Menjadi manusia yang baik. Menjadi manusia yang baik otomatis akan menjadi warga negara yang baik. Tapi warga negara yang baik, belum tentu menjadi manusia yang baik.

2. Berpikir secara kritis, rasional, dan kreatif dalam menanggapi isu kewarganegaraan

3. Berpartisipasi secara aktif dan bertanggung jawab; bertindak secara cerdas dalam kegiatan bermasyarakat, berbangsa, dan bernegara, serta anti-korupsi

c. Bahasa Indonesia

Bahasa merupakan materi pokok terpenting - setelah agama yang harus diberikan kepada murid. Pendidikan adalah produk bahasa dan bergantung pada bahasa. Pendidikan melibatkan komunikasi, interpretasi, analisis, sintesis, internalisasi, dan aplikasi konsep-konsep, ide-ide, sekaligus merefleksikan realitas, yang kesemuanya memerlukan peranan bahasa. 
Bahasa Indonesia adalah kunci pertama untuk memahami bahasa-bahasa yang lain. Karenanya menguasai Bahasa Indonesia bersifat fardlu ain. Mustahil bisa memahami bahasa asing dengan baik bila peguasaan terhadap bahasa ibu ini tidak baik. Mata pelajaran Bahasa Indonesia bertujuan agar peserta didik memiliki kemampuan sebagai berikut :

1. Berkomunikasi secara efektif dan efisien sesuai dengan etika yang berlaku, baik secara lisan maupun tulis

2. Menghargai dan bangga menggunakan bahasa Indonesia sebagai bahasa persatuan dan bahasa negara

3. Memahami bahasa Indonesia dan menggunakannya dengan tepat dan kreatif untuk berbagai tujuan

4. Menggunakan bahasa Indonesia untuk meningkatkan kemampuan intelektual, serta kematangan emosional dan sosial

5. Menikmati dan memanfaatkan karya sastra untuk memperluas wawasan, memperhalus budi pekerti, serta meningkatkan pengetahuan dan kemampuan berbahasa

6. Menghargai dan membanggakan sastra Indonesia sebagai khazanah budaya dan intelektual manusia Indonesia.

d. Bahasa Inggris

Tujuannya adalah agar peserta didik dapat:

1. Menjadi skilled performer dalam bahasa Inggris atau mengembangkan kompetensi berkomunikasi dalam bentuk lisan dan tulisan untuk mengiringi tindakan (language accompanying action)

2. Memiliki kesadaran tentang hakikat dan pentingnya bahasa Inggris untuk meningkatkan kejayaan Islam

e. Matematika

Pengajaran matematika dimaksudkan agar murid terlatih untuk mengkomunikasikan konsep-konsep abstrak ke dalam bentuk operasional. Rumus-rumus yang ada pada matematika bersifat 
pasti, namun penerjemahannya dalam bentuk penyelesaian soalsoal membutuhkan pemahaman yag komprehensif. Seseorang yang mengetahui rumus matematika tidak dengan sendirinya dapat menyelesaikan soal-soal dengan tepat. Sifat matematika yang seperti ini, mendorong murid untuk jeli, cermat, mempercayai bahwa realitas alam dan sosial memilki kepastian hukum. Hukum mengikat apa pun yang ada dalam wilayahnya berdasarkan kaidah yang telah ditentukan. Hukum ada yang bersifat sederhana, ada yang bersifat kompleks. Keduanya bukan berlawanan. Yang sederhana merupakan penyusun yang kompleks. Yang kompleks tidak bisa terbangun tanpa sederhana. Matematika sendiri adalah unsur yang diperlukan untuk memahami dan menguasai ilmuilmu pengetahuan alam.

Pengajaran matematika berorientasi memberikan pemahaman yang kuat terhadap konsep-konsep dasar matematika. Para siswa harus memiliki bangunan konsep matematika yang kuat sebelum memperoleh pembelajaran operasi matematika. Pengajaran yang langsung berorientasi pada operasi matematika memiliki beberapa kerugian:

Pertama, mereka tidak memilki basis pemahaman untuk kelak mengembangkan matematika dan ilmu-ilmu lain - karena masingmasing ilmu bukan disiplin yang berdiri sendiri dan terpisah.

Kedua, sebagai konsekuensi, murid kurang mampu mengkomunikasikan rumusan matematika ke dalam realitas psikis, sejarah, dan sosial.

Ketiga, murid yang menyukai matematika akan cenderung memiliki pola berpikir yang langsung, bukan sistemik.

Keempat, cara ini cenderung membuat murid tidak dapat berkomunikasi dengan rumus-rumus matematika yang mereka hadapi. Ini menimbulkan jarak psikis antara murid dan matematika, sehingga murid sulit untuk menyukai matematika. Bahkan ketidaksukaan pada matematika ini bisa berimbas pada ilmu-ilmu kealaman yang memilki unsur matematika.

Selama mengajarkan konsep-konsep dasar matematika, guru juga perlu memberikan wawasan kepada murid tentang "penggunaan" hukum matematika dalam menjawab persoalan sehari-hari. Guru juga 
perlu mengkomunikasikan muatan tauhid dari hukum matematika, misalnya menjelaskan tentang sejarah angka 0 (nol).

Mata pelajaran matematika bertujuan agar peserta didik memiliki kemampuan sebagai berikut :

1. Memahami konsep matematika, menjelaskan keterkaitan antar konsep dan mengaplikasikan konsep atau algoritma.

2. Menggunakan penalaran pada pola dan sifat.

3. Memecahkan masalah yang meliputi kemampuan memahami masalah, merancang model matematika, menyelesaikan model dan menafsirkan solusi yang diperoleh.

4. Mengomunikasikan gagasan dengan simbol, tabel, diagram, atau media lain untuk memperjelas keadaan atau masalah.

5. Memiliki sikap menghargai kegunaan matematika dalam kehidupan, yaitu memiliki rasa ingin tahu, perhatian, dan minat dalam mempelajari matematika, serta sikap ulet dan percaya diri dalam pemecahan masalah.

f. Sains

Demikian strategisnya penyingkapan realitas kealaman untuk menjadi pendorong religius dan akhlak karimah bagi manusia, sehingga Al Qur'an memuat banyak sekali ayat tentang seruan untuk mengamati dan memikirkan rahasia realitas kealaman.

Pemberian materi sains ini harus berpijak pada pandangan dunia tauhid, sehingga ilmu yang diperoleh benar-benar mengantarkan murid kepada pengenalan terhadap Allah. Pemberian meteri sains dengan berpijak pada pandangan dunia bukan tauhid, justru dapat menjauhkan murid dari iman kepada Allah. Bertambahnya ilmu tentang alam, justru menjadikan hati murid tertutupi oleh kebenaran. Kondisi inilah yang saat ini terjadi di Barat, yang disebabkan oleh tradisi keilmuannya yang bersumber pada filsafat materialisme ( salah satu produknya, misalnya, teori evolusi Darwin).

Pandangan dunia tauhid dalam hubungan dengan ilmu ini sejak semula telah ditanamkan dalam wahyu pertama, yaitu surah al-Alaq 1-5. Dengan pelajaran IPA yang berpijak pada pandangan dunia 
tauhid ini, ilmu yang turun kepada siswa diharapkan bisa sampai pada tingkatan hati, bukan hanya sampai pada tingkatan mata/ indra dan akal. Contoh:

Pada tingkatan mata/indra : orang akan mengatakan bahwa bintang di langit itu kecil, karena ia tidak memiliki pengetahuan.

Pada tingkatan akal : orang akan mengatakan bahwa sebenarnya bintang di langit itu besar, karena ia memiliki pengetahuan.

Pada tingkatan hati: orang akan mengatakan bahwa bintang di langit itu kecil, meskipun ia tahu bahwa sebenarnya bintang itu besar. Karena ia tahu bahwa bila dibanding dengan kebesaran Allah SWT kecil, bintang itu amat kecil.

Jika sampainya ilmu itu pada murid hanya berhenti pada tingkatan indra dan akal - yang merupakan basis metode ilmiah pada saat ini, maka siswa akan jatuh pada paham atheis dan materialisme yang merupakan syirik terbesar abad ini. Yang kita inginkan adalah dari pelajaran IPA ini akan lahir para generasi ulil albab seperti yang tercermin pada surah Ali-Imron : 190-191.

Pengajaran sains ditekankan pada penguasaan konsep-konsep dasar. Ini sangat penting bagi murid, kelak ketika mereka mulai mempelajari ilmu-ilmu kealaman lanjut. Lemahnya konsep-konsep dasar dan titik berat pengajaran yang hanya berorientasi pada penghafalan, bukan pemahaman, menyulitkan murid untuk menarik keterkaitan hubungan antar hal secara memadai. Pada kondisi yang demikian, pola berpikir yang inovatif sulit tumbuh pada murid.

Mata Pelajaran sains bertujuan agar peserta didik dapat :

1. Memperoleh keyakinan terhadap kebesaran Tuhan Yang Maha Esa berdasarkan keberadaan, keindahan dan keteraturan alam ciptaan-Nya

2. Mengembangkan pengetahuan dan pemahaman konsep-konsep IPA yang bermanfaat dan dapat diterapkan dalam kehidupan sehari-hari

3. Mengembangkan rasa ingin tahu, sikap positif dan kesadaran tentang adanya hubungan yang saling mempengaruhi antara IPA, lingkungan, teknologi dan masyarakat 
4. Mengembangkan keterampilan proses untuk menyelidiki alam sekitar, memecahkan masalah dan membuat keputusan

5. Meningkatkan kesadaran untuk berperan serta dalam memelihara, menjaga dan melestarikan lingkungan alam

6. Meningkatkan kesadaran untuk menghargai alam dan segala keteraturannya sebagai salah satu ciptaan Tuhan

7. Memperoleh bekal pengetahuan, konsep dan keterampilan IPA sebagai dasar untuk melanjutkan pendidikan ke jenjang selanjutnya.

g. Ilmu Pengetahuan Sosial

Mata pelajaran IPS bertujuan agar peserta didik memiliki kemampuan sebagai berikut :

1. Mengenal konsep-konsep yang berkaitan dengan kehidupan masyarakat dan lingkungannya.

2. Memiliki kemampuan dasar untuk berpikir logis dan kritis, rasa ingin tahu, inkuiri, memecahkan masalah, dan keterampilan dalam kehidupan sosial.

3. Memiliki komitmen dan kesadaran terhadap nilai-nilai sosial dan kemanusiaan yang diajarkan oleh Islam.

4. Memiliki kemampuan berkomunikasi, bekerjasama dan berkompetisi dalam masyarakat yang majemuk, di tingkat lokal, nasional, dan global.

h. Pendidikan Jasmani, Olahraga, dan Kesehatan

Pendidikan Jasmani, Olahraga, dan Kesehatan bertujuan agar peserta dapat :

1. Mengembangkan keterampilan pengelolaan diri dalam upaya pengembangan dan pemeliharaan kebugaran jasmani serta pola hidup sehat melalui berbagai aktivitas jasmani dan olahraga yang terpilih.

2. Meningkatkan pertumbuhan fisik dan pengembangan psikis yang lebih baik.

3. Meningkatkan kemampuan dan keterampilan gerak dasar. 
4. Meletakkan landasan karakter moral yang kuat.

5. Mengembangkan sikap sportif, jujur, disiplin, bertanggungjawab, kerjasama, percaya diri dan demokratis.

6. Mengembangkan keterampilan untuk menjaga keselamatan diri sendiri, orang lain dan lingkungan.

7. Memahami konsep aktivitas jasmani dan olahraga di lingkungan yang bersih sebagai informasi untuk mencapai pertumbuhan fisik yang sempurna, pola hidup sehat dan kebugaran, terampil, serta memiliki sikap yang positif.

i. Teknologi Informasi dan Komunikasi

Materi komputer dan IT bertujuan agar peserta didik memiliki kemampuan sebagai berikut :

1. Memiliki kesadaran tentang hakikat dan pentingnya teknologi untuk meningkatkan daya saing bangsa dalam masyarakat global.

2. Mengembangkan kompetensi untuk dapat berinteraksi dengan bangsa lain dalam percaturan dunia secara langsung atau tidak langsung dengan memanfaatkan teknologi informasi dan komunikasi.

j. Seni Budaya

Mata pelajaran seni budaya bertujuan agar peserta didik memiliki kemampuan sebagai berikut:

1. memahami pentingnya seni budaya

2. menampilkan sikap apresiasi terhadap seni budaya

3. menampilkan kreativitas melalui seni budaya

4. menampilkan peran serta dalam seni budaya di tingkat lokal, regional maupun global

Setiap kurikulum memiliki tujuan dan maksud tersendiri yang pasti berbeda dengan kurikulum yang lainnya. Hal tersebut dilakukan agar guru sebagai pengajar dan pendidik tidak keluar dari topik yang telah ditentukan dalam tujuan kurikulum tersebut. Misalnya, 
kurikulum estetika mempunyai tujuan untuk meningkatkan sensitivitas, kemampuan mengekspresikan dan mengapresiasi keindahan dan harmoni. Kemampuan itu mencakup apresiasi dan ekspresi baik dalam kehidupan individual sehingga mampu menikmati dan mensyukuri hidup, maupun dalam kehidupan sosial sehingga mampu menciptakan kebersamaan yang harmonis. Dalam mendukung kurikulum ini, maka mata pelajarannya adalah pelajaran seni budaya yang apabila anak didik ini mempelajari mata pelajaran ini, dianggap mampu memahami pentingnya seni budaya. Pada akhirnya akan menampilkan sikap apresiasi terhadap seni budaya serta kreativitas melalui seni budaya di tingkat lokal, regional maupun global. Penjelasan tentang kurikulum ini sudah sangat jelas dan gambarannya juga tidak perlu memunculkan asumsi yang lain. Oleh karena itu, apabila tidak terdapat pembahasan tentang gender dalam kurikulum, baik dalam cakupan mata pelajaran maupun penjabaran tujuan, maka kesadaran gender pada anak usia dini akan menjadi terabaikan.

\section{F. Penutup}

Sistem pendidikan sebagai sebuah alat dan metode dalam membuat sebuah perubahan. Perubahan sosial terjadi apabila melibatkan sistem pendidikan ramah terhadap isu gender. Tatanan sosial yang berdasar pada gender bertujuan untuk membangun sebuah kehidupan yang harmonis dimana hubungan antara laki-laki dan perempuan berdasar pada nilai-nilai keseimbangan. Apabila kehidupan dibangun berdasarkan perbedaan laki-laki dan perempuan atas nilai, norma, budaya dan agama maka ketidakharmonisan yang akan terjadi. Laki-laki dan perempuan bersaing dan saling bercerai berai memperebutkan posisi yang menguntungkan sehingga terpenuhi kebutuhan hidupnya.

Pemahaman tentang gender ditentukan oleh bagaimana seseorang tersebut memahami laki-laki dan perempuan berdasarkan ruang dan waktu. Masa dimana seseorang dalam sebuah tatanan pendidikan yang berbasis sekolah dasar Islam menjadi sebuah masa yang dapat mempengaruhi pola pikir seseorang sehingga kelak di kemudian hari akan menjadi seorang dewasa yang memilki perspektif matang tentang gender. Ketepatan pemahaman dalam membedakan laki-laki dalam perempuan dalam kondisi ruang dan waktu akan menciptakan sebuah keharmonisan dalam kehidupan. Keharmonisan dalam kehidupan 
menjadi sebuah cita-cita yang harus dibangun bersama-sama antara laki-laki dan perempuan sehingga dapat memenuhi kebutuhan dan mancapai keberlangsungan hidup dengan baik. Kajian ini dilakukan untuk membuktikan tentang keberadaan kurikulum pada anak sekolah dasar sebagai upaya memahamkan perbedaan antara laki-laki dengan perempuan. Pemahaman ini sangat penting dalam mempersiapkan mental anak dalam menghadapi masa dimana akan terjadi perubahan yang besar dalam menghadapi masa baligh yang ditandai perubahan fisik. Hasil dari kajian ini menunjukkan secara signifikan bahwa tidak ada kurikulum yang dengan jelas dan tersirat dalam mengupas tentang gender.

\section{Daftar Pustaka}

Eicher., Nadine dan Jansen . 2013. Gender Acquisition in bilingual children. French-german, Italian-German, Spanish-german and ItalianFrench.

Sultan dan Mehmet. 2006. Possible Gender Identity Disorder in Extremely Religious Muslim family. Spinger Science and Business Media. Istambul. Turkey.

Data sekunder. 2014. Kurikulum tahun 2012 Sekolah Dasar Alam ArRohmah Putri Yayasan Hidayatullah. Malang.

Barlas, Asma. 2003. Cara Qur'an membebaskan Perempuan. Serambi Ilmu Semesta. P: 14-18. Jakarta.

Mufidah. 2010. Gender di Pesantren Salaf Why Not....? Menulusuri Jejak Konstruksi Sosial Pengarusataman Gender di Kalangan di Kalangan Elit Santri. UIN Maliki Press, Malang.

Yusuf Koc, Mine Isiksal, Safure Bulut. 2007. Elementary School Curriculum Reform in Turkey. Shannon Research Press. Turkey.

Ritzer, George dan Goodman, Douglas J . 2005. Teori Sosiologi Modern. Perdana Media. Jakarta. 
